\title{
A MiniSandwich Experiment with Blended Ca-Bentonite and Pearson Water-Hydration, Swelling, Solute Transport and Cation Exchange
}

\author{
Katja Emmerich ${ }^{1, * \mathbb{D}}$, Eleanor Bakker ${ }^{1}{ }^{\mathbb{D}}$, Franz Königer ${ }^{2}$, Christopher Rölke $^{3}$, Till Popp ${ }^{3}$, Sarah Häußer ${ }^{4}$, \\ Ralf Diedel ${ }^{4}$ and Rainer Schuhmann ${ }^{1,2}$ \\ 1 Karlsruher Institut für Technologie (KIT), Kompetenzzentrum für Materialfeuchte (IMB-CMM), \\ 76344 Eggenstein-Leopoldshafen, Germany; eleanor.bakker@kit.edu (E.B.); rainer.schuhmann@kit.edu (R.S.) \\ 2 Ingenieur-Gesellschaft für Sensorik in der Umwelttechnik mbH (ISU), 76185 Karlsruhe, Germany; \\ franz.koeniger@isu-karlsruhe.com \\ 3 Institut für Gebirgsmechanik (IfG), 04279 Leipzig, Germany; christopher.roelke@ifg-leipzig.de (C.R.); \\ till.popp@ifg-leipzig.de (T.P.) \\ 4 Stephan Schmidt KG, 65599 Dornburg-Langendernbach, Germany; Sarah.Haeusser@schmidt-tone.de (S.H.); \\ ralf.diedel@schmidt-tone.de (R.D.) \\ * Correspondence: katja.emmerich@kit.edu
}

Citation: Emmerich, K.; Bakker, E.;

Königer, F;; Rölke, C.; Popp, T.;

Häußer, S.; Diedel, R.; Schuhmann, R. A MiniSandwich Experiment with Blended Ca-Bentonite and Pearson Water-Hydration, Swelling, Solute Transport and Cation Exchange. Minerals 2021, 11, 1061. https:// doi.org/10.3390/min11101061

Academic Editors: Ana

María Fernández, Stephan Kaufhold, Markus Olin, Lian-Ge Zheng, Paul Wersin and James Wilson

Received: 29 July 2021

Accepted: 23 September 2021

Published: 28 September 2021

Publisher's Note: MDPI stays neutral with regard to jurisdictional claims in published maps and institutional affiliations.

Copyright: (c) 2021 by the authors. Licensee MDPI, Basel, Switzerland. This article is an open access article distributed under the terms and conditions of the Creative Commons Attribution (CC BY) license (https:// creativecommons.org/licenses/by/ $4.0 /)$.
Abstract: Shaft seals are geotechnical barriers in nuclear waste deposits and underground mines. The Sandwich sealing system consists of alternating sealing segments (DS) of bentonite and equipotential segments (ES). MiniSandwich experiments were performed with blended Ca-bentonite $(90 \mathrm{~mm}$ diameter and $125 \mathrm{~mm}$ height) to study hydration, swelling, solute transport and cation exchange during hydration with A3 Pearson water, which resembles pore water of Opalinus Clay Formation at sandy facies. Two experiments were run in parallel with DS installed either in one-layer hydrate state $(1 \mathrm{~W})$ or in air-dry two-layer hydrate $(2 \mathrm{~W})$ state. Breakthrough at $0.3 \mathrm{MPa}$ injection pressure occurred after 20 days and the fluid inlet was closed after 543 days, where $4289 \mathrm{~mL}$ and $2984 \mathrm{~mL}$, respectively, passed both cells. Final hydraulic permeability was $2.0-2.7 \times 10^{-17} \mathrm{~m}^{2}$. Cells were kept for another 142 days before dismantling. Swelling of DS resulted in slight compaction of ES. No changes in the mineralogy of the DS and ES material despite precipitated halite and sulfates occurred. Overall cation exchange capacity of the DS does not change, maintaining an overall value of $72 \pm 2 \mathrm{cmol}(+) / \mathrm{kg}$. Exchangeable $\mathrm{Na}^{+}$strongly increased while exchangeable $\mathrm{Ca}^{2+}$ decreased. Exchangeable $\mathrm{Mg}^{2+}$ and $\mathrm{K}^{+}$remained nearly constant. Sodium concentration in the outflow indicated two different exchange processes while the concentration of calcium and magnesium decreased potentially. Concentration of sulfate increased in the outflow, until it reached a constant value and chloride concentration decreased to a minimum before it slightly increased to a constant value. The available data set will be used to adapt numerical models for a mechanism-based description of the observed physical and geochemical processes.

Keywords: anion distribution; CEC; exchangeable cations; hydration; MiniSandwich; sandwich sealing system; solute transport; swelling pressure

\section{Introduction}

Shaft and drift-sealing systems for a nuclear waste repository and in deep underground mines limit the fluid inflow from the adjacent rock in the early stage after closure of the repository or a mine. In mines, partial active areas are protected from sudden fluid inflow, and in repositories and mines the release of possibly contaminated fluids at later stage are prevented, or at least delayed [1]. Current German concepts of shaft seals of nuclear waste repositories contain the hydraulic Sandwich sealing system as a component of the lower seal in the host rock [2]. 
The Sandwich sealing system consists of alternating sealing segments (DS) of bentonite and equipotential segments (ES), which are characterized by a higher hydraulic conductivity. Within ES, fluid is evenly distributed over the cross section of the seal. Water bypassing the seal via the excavation damaged zone (EDZ) or penetrating the seal inhomogeneously is contained and a more homogeneous hydration and swelling of the DS is obtained.

Proof of functionality of the system has been provided in semi-technical scale experiments [3,4] for different host rocks. In 2019, an in-situ large-scale experiment was launched at the Mont Terri Rock Laboratory (Mont Terri RL, Switzerland) in the sandy facies of the Opalinus clay to address the interaction between the sealing system and a potential host rock [5]. The sandy facies of the Opalinus clay at Mont Terri RL corresponds to the clay formation in the generic site model SOUTH [6] of the potential clay host rock in Germany.

Additional semi-technical scale experiments and extensive laboratory tests are carried out for material development and material parametrization to supplement the in-situ experiment by modeling. The current study covered MiniSandwich experiments [7] with blended Ca-bentonite to study hydration, swelling, solute transport and cation exchange during hydration with Pearson water.

The pore water of the Opalinus clay at Mont Terri Rock Laboratory (Mont Terri RL) (Pearson water) contains $150-250 \mathrm{mmol} \cdot \mathrm{L}^{-1} \mathrm{NaCl}$. The concentration of divalent cations and anions is lower than $15 \%$ of the cations and anions, respectively [8-10].

The current German concept for engineered barriers does not specify a bentonite but two national bentonites from Bavaria (Calcigel, Clariant) and Westerwald (Secursol UHP, Stephan Schmidt KG) would be available [5]. Both bentonites are Ca-bentonites. Cation exchange in the interlayer of the swellable clay minerals [11], together with anion exchange, dissolution, and precipitation of secondary phases will take place during the hydration of the sealing system with a pore fluid, mainly containing sodium cations until geochemical equilibrium is obtained. Thereby, alteration of the hydration of the bentonites as well as hydraulic conductivity and swelling pressure is expected.

Cation exchange and reactive solute transport during the early stage of the hydration of engineered barriers was observed at elevated temperatures from the Long-Term Test of Buffer Material (LOT) and the Alternative Buffer Material (ABM) test at Äspö Hard Rock Laboratory (Äspö HRL) (e.g., [12-15]), but pore fluid composition at Äspö HRL and Mont Terri RL differ in composition and sealing systems will not be exposed to elevated temperatures. The objective of the current study was to enhance the understanding of hydromechanical behavior and reactive solute transport during hydration of a Sandwichsealing system composed of Ca-bentonite under the inflow of A3 Pearson water, which resembles Opalinus Clay pore water at sandy facies $[8,9]$.

\section{Materials and Methods}

\subsection{Materials and Experimental Setup}

Fine sand N45 (Nivelsteiner Sandwerke und Sandsteinbrüche GmbH, Herzogenrath, Germany) [11] was used for ES. The bentonite Secursol UHP (Ruppach, Lower Saxony, Germany) by the Stephan Schmidt group (Langendernbach, Germany) with a smectite content of about $80 \%$ (Table 1) from a batch of granular material, also used in a semitechnical scale experiment (HTV-6), was used in a material blend for the DS. The specific density $\left(\rho_{\mathrm{s}}\right)$ of Secursol UHP of $2.77 \mathrm{~g} / \mathrm{cm}^{3}$ calculated from the phase content was confirmed by measurement after drying at $200{ }^{\circ} \mathrm{C}$ with a He pycnometer (Pycnomatic ATC Porotec, Hofheim, Germany). 
Table 1. Phase content determined by XRD and specific grain density * of Secursol UHP.

\begin{tabular}{cccc}
\hline Phase & $\begin{array}{c}{[\mathbf{w t} \% \text { \% }} \\
\mathbf{2 W}\end{array}$ & $\begin{array}{c}{[\mathbf{w t .} \%]} \\
\text { Anhydrous }\end{array}$ & $\begin{array}{c}\boldsymbol{\rho}_{\mathbf{s}}\left[\mathbf{g} / \mathbf{c m}^{\mathbf{3}}\right]^{*} \\
\text { Anhydrous }\end{array}$ \\
\hline Smectite (di) & 79 & 75 & 2.75 \\
Quartz & 10 & 12 & 2.66 \\
Kaolinite & 2 & 2 & 2.6 \\
Mica (di) & 3 & 4 & 2.75 \\
Feldspar (orthoclase) & 2 & 2 & 2.61 \\
Anatase & 3 & 4 & 3.78 \\
Traces $§$ & 1 & 1 & 3.16 \\
Total & 100 & 100 & 2.77
\end{tabular}

Note: ${ }^{*} \rho_{\mathrm{s}}$ calculated based on crystal structure. \# air dried at ambient conditions with a $2 \mathrm{~W}$ hydration state and water content of about $15.4 \%$ (measured at $200^{\circ} \mathrm{C}$ ). $\S$ apatite, rutile, hematite, maghemite (all detectable by XRD) and carbonates (only detectable by STA).

The Westerwald bentonite is from the Miocene age and consists of highly altered tuffs from the late Oligocene age. Secursol UHP is characterized by a very high swelling pressure of $>4 \mathrm{MPa}$ at a dry density of about $1.55 \mathrm{~g} / \mathrm{cm}^{3}$, which even exceeds $10 \mathrm{MPa}$ at higher dry densities [5]. Therefore, the bentonite was blended with N45 to reduce its smectite content, and thus its swelling pressure, to avoid damage of the oedometer cells.

Pearson water [16] close to A3 composition $[8,17]$ which resembles the pore fluid of the sandy facies of Opalinus clay at Mont Terri URL [9] (Table 2), perfused the MiniSandwich columns. The ionic strength was $0.5 \mathrm{M}$. The Pearson water was prepared in two batches.

Table 2. Pearson water composition at sandy facies of Opalinus Clay [8], $\mathrm{pH}$ and liquid density $\left(\rho_{1}\right)$.

\begin{tabular}{|c|c|c|c|c|c|c|c|c|c|c|}
\hline Title & $\mathrm{Na}^{+}$ & $\mathrm{Ca}^{2+}$ & $\mathrm{Mg}^{2+}$ & $\mathrm{K}^{+}$ & $\mathrm{HCO}_{3}{ }^{-}$ & $\mathrm{Cl}^{-}$ & $\mathrm{SO}_{4}{ }^{2-}$ & $\mathrm{Cl}^{-} / \mathrm{SO}_{4}{ }^{2-}$ & $\mathrm{pH}$ & $\rho_{1}$ \\
\hline \multicolumn{8}{|c|}{$[\mathrm{mmol} / \mathrm{L}]$} & {$[-]$} & {$[-]$} & {$\left[\mathrm{g} / \mathrm{cm}^{3}\right]$} \\
\hline Target ${ }^{1}$ & 164 & 11.9 & 9.2 & 2.55 & 0.54 & 160 & 24 & 6.67 & 7.9 & 1.01 \\
\hline Batch $1^{2}$ & 153 & 11.6 & 8.7 & 2.5 & n.d. & 150 & 24 & 6.25 & 7.7 & 1.01 \\
\hline Batch 2 & 230 & 15.9 & 11.37 & 4.06 & n.d. & $230^{3}$ & $30^{3}$ & 7.67 & n.d. & n.d. \\
\hline & & \multicolumn{4}{|c|}{$[\mathrm{mg} / \mathrm{L}]$} & \multicolumn{5}{|c|}{$[-]$} \\
\hline Target ${ }^{1}$ & 3770 & 477 & 224 & 100 & 33 & 5672 & 2305 & 2.46 & & \\
\hline Batch $1^{2}$ & 3517 & 465 & 211 & 98 & n.d. & 5318 & 2305 & 2.31 & & \\
\hline Batch 2 & 5288 & 637 & 276 & 159 & n.d. & 8154 & 2882 & 2.83 & & \\
\hline
\end{tabular}

Note: ${ }^{1}[9,16] .{ }^{2}[5] .{ }^{3}$ estimated from cation content. n.d. not determined.

The MiniSandwich specimens consisted of three ES sandwiched by two DS of blended bentonite (Figure 1b), separated by filter papers (manufacturer: Macherey-Nagel, material: cellulose, pore size: $7.0-12.0 \mu \mathrm{m})$. The diameter of the columns was $90 \mathrm{~mm}$ and a total sample height of $125 \mathrm{~mm}$ was envisaged. Actual sample heights of 130 and $131 \mathrm{~mm}$, respectively, were obtained (Table 3). Sample heights decreased to 129.2 and $129.8 \mathrm{~mm}$, respectively, by applying the axial load prior to the start of the hydration.

Two experiments were run in parallel with the bentonite in DS, installed either in air-dry state (cell 10) or after conditioning by drying over a concentrated $\mathrm{H}_{2} \mathrm{SO}_{4}$ solution atmosphere for several months (cell 9) to study different initial hydration states of the smectite (Table 4). The water content of the bentonite determined at $\left(105^{\circ} \mathrm{C}\right) 200^{\circ} \mathrm{C}$ was $(13.3 \%) 16.5 \%$ in air dry state and $(0.9 \%) 3.9 \%$ after drying at very low relative humidity. Only the water content determined at $200{ }^{\circ} \mathrm{C}$ will be used for further calculations. 


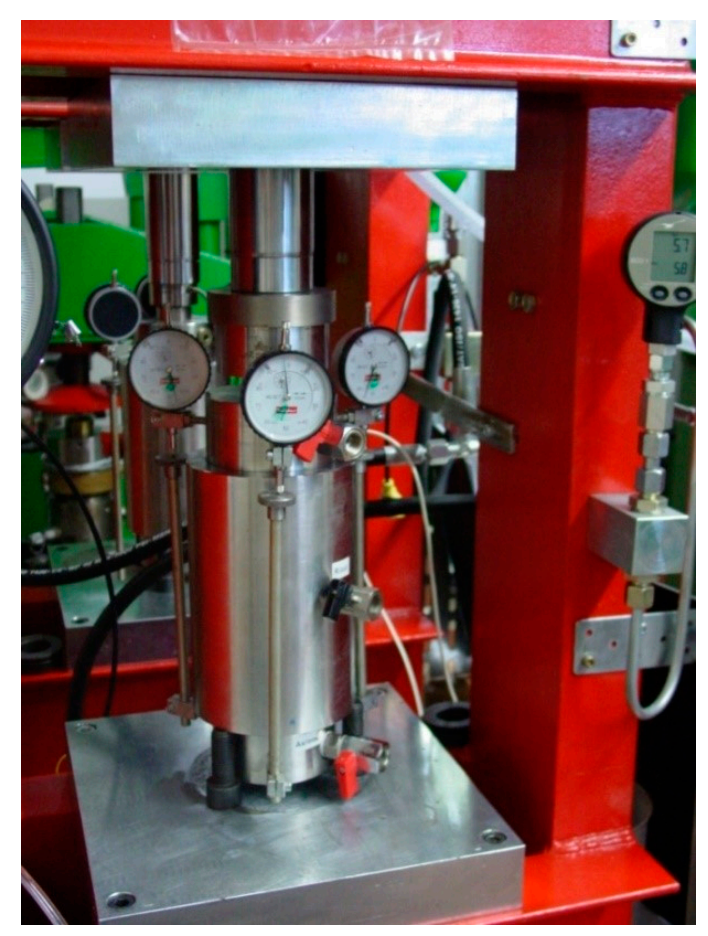

(a)

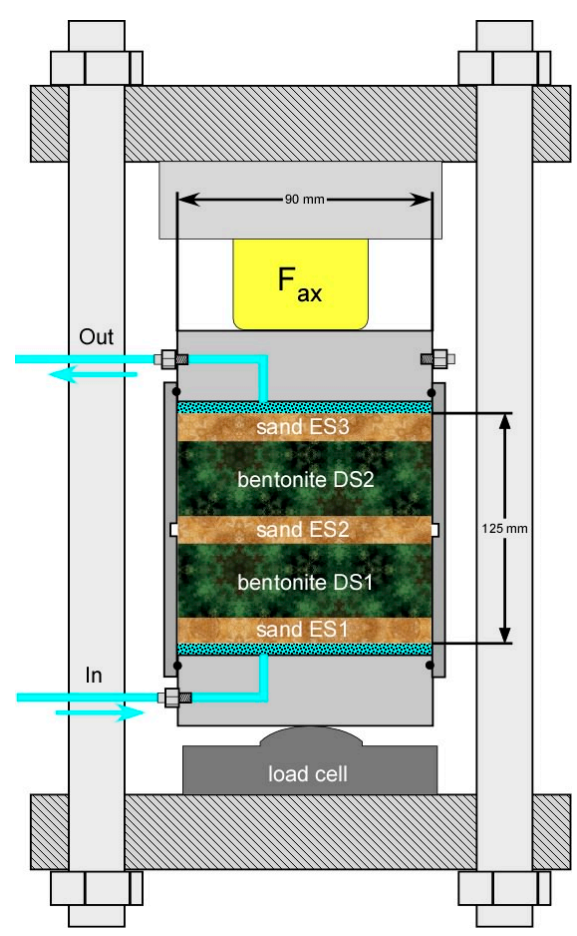

(b)

Figure 1. Experimental setup. (a) Hydraulic testing rig with oedometer cell. Note the three strain gauges, measuring the axial displacement over the sample lengths; (b) Schematic sketch of the oedometer cell.

Table 3. Installation bulk $\left(\rho_{\mathrm{b}}\right)$ and dry density $\left(\rho_{\mathrm{d}}\right)$, porosity $(\mathrm{n})$, pore volume $\left(\mathrm{V}_{\mathrm{p}}\right)$, volume of water in pores during installation $\left(\mathrm{V}_{\mathrm{w}, \mathrm{i}} \mathrm{i}\right)$ and saturation water content $\left(\mathrm{w}_{\mathrm{S}}\right)$ of cells 9 and 10 .

\begin{tabular}{ccccccccc}
\hline \multirow{2}{*}{ Cell $\mathbf{9}$} & $\mathbf{m}$ & $\mathbf{h}$ & $\boldsymbol{\rho}_{\mathbf{b}}$ & $\boldsymbol{\rho}_{\mathbf{d}}$ & $\mathbf{n}$ & $\mathbf{V}_{\mathbf{p}}$ & $\mathbf{V}_{\mathbf{w}, \mathbf{i}}$ & $\mathbf{w}_{\mathbf{s}}$ \\
\cline { 2 - 8 } & $\mathbf{g}]$ & {$[\mathbf{m m}]$} & {$\left[\mathbf{g} / \mathbf{c m}^{\mathbf{3}}\right]$} & {$\left[\mathbf{g} / \mathbf{c m}^{\mathbf{3}}\right]$} & {$[\%]$} & {$[\mathbf{m L}]$} & {$[\mathbf{m L}]$} & {$[\%]$} \\
\hline ES3 & 158.79 & 16 & 1.56 & 1.56 & 41.4 & 42.1 & 0 & 26.77 \\
DS2 & 357.2 & 42 & 1.34 & 1.30 & 52.8 & 141.1 & 10.6 & 41.33 \\
ES2 & 158.79 & 16 & 1.56 & 1.56 & 41.4 & 42.1 & 0 & 26.77 \\
DS1 & 357.3 & 41 & 1.37 & 1.33 & 51.7 & 134.7 & 10.6 & 39.25 \\
ES1 & 158.79 & 16 & 1.56 & 1.56 & 41.4 & 42.1 & 0 & 26.77 \\
Sum & 1190.87 & 131 & & & 48.3 & 402.2 & 21.2 & \\
\hline & $\mathbf{m}$ & $\mathbf{h}$ & $\boldsymbol{\rho}_{\mathbf{b}}$ & $\boldsymbol{\rho}_{\mathbf{d}}$ & $\mathbf{n}$ & $\mathbf{V}_{\mathbf{p}}$ & $\mathbf{V}_{\mathbf{w}, \mathbf{i}}$ & $\mathbf{w}_{\mathbf{s}}$ \\
Cell 10 & {$[\mathbf{g}]$} & {$[\mathbf{m m}]$} & {$\left[\mathbf{g} / \mathbf{c m}^{\mathbf{3}}\right]$} & {$\left[\mathbf{g} / \mathbf{c m}^{3}\right]$} & {$[\%]$} & {$[\mathbf{m L}]$} & {$[\mathbf{m L}]$} & {$[\%]$} \\
\hline ES3 & 158.80 & 16 & 1.56 & 1.56 & 41.3 & 42.1 & 0 & 26.77 \\
DS2 & 370.31 & 41 & 1.42 & 1.26 & 54.3 & 141.5 & 42.3 & 43.58 \\
ES2 & 158.80 & 16 & 1.56 & 1.56 & 41.3 & 42.1 & 0 & 26.77 \\
DS1 & 391.42 & 41 & 1.50 & 1.33 & 51.7 & 134.7 & 44.7 & 39.25 \\
ES1 & 158.80 & 16 & 1.56 & 1.56 & 41.3 & 42.1 & 0 & 26.77 \\
Sum & 1238.13 & 130 & & & 48.7 & 401.7 & 87.0 & \\
\hline
\end{tabular}


Table 4. Water content of DS, hydration state of smectite and gas permeability during installation and final swelling pressure and fluid permeability of cell 9 and cell 10.

\begin{tabular}{cccc}
\hline Parameter & Unit & Cell 9 & Cell 10 \\
\hline Water content, $\mathrm{W}\left(200^{\circ} \mathrm{C}\right)$ & {$[\%]$} & 3.1 & 12.9 \\
Hydration state of smectite & & $1 \mathrm{~W}$ & $2 \mathrm{~W}$ \\
Gas permeability & {$\left[\mathrm{m}^{2}\right]$} & $8.7 \times 10^{-12}$ & $5.6 \times 10^{-12}$ \\
Swelling pressure & {$[\mathrm{MPa}]$} & 0.7 & 0.6 \\
Fluid permeability & {$\left[\mathrm{m}^{2}\right]$} & $2.0 \times 10^{-17}$ & $2.7 \times 10^{-17}$ \\
\hline
\end{tabular}

One aliquot of bentonite (dry weight) was mixed with 0.28 aliquots of N45 (water content $<0.1 \%$ ) resulting in a starting water content in DS of $3.1 \%$ (cell 9) and $12.9 \%$ (cell 10). The specific density of the blend was $2.75 \mathrm{~g} / \mathrm{cm}^{3}$. The bentonite sand mixture could be compacted only to a dry density $\left(\rho_{\mathrm{d}}\right)$ between 1.26 and $1.33 \mathrm{~g} / \mathrm{cm}^{3}$ (Table 3), and a very low resulting EMDD (Dixon et al. 1985) between 0.95 and $1.02 \mathrm{~g} / \mathrm{cm}^{3}$. The N45 in ES was installed with a $\rho_{\mathrm{d}}$ of $1.56 \mathrm{~g} / \mathrm{cm}^{3}$.

For the MiniSandwich experiments modified oedometer cells with two movable pistons and filter plates for adjusting well-defined saturation conditions [18] were located in hydraulic load frames (Figure 1a). The axial strain/displacement was measured by three gauges (rotated by $120^{\circ}$ ) and was regularly reset to zero by increasing or decreasing the axial load measured by a load cell. Thus, during the tests, axial expansion due to swelling of the sample has been reset recompacting the material to the initial volume to keep the MiniSandwich under quasi-constant volume conditions.

After installation, the initial gas permeability defined the starting conditions. It was determined with nitrogen by average of five measurements of the gas pressure difference to atmospheric pressure (0.12-0.18 MPa) at gas flow between 200 and $1000 \mathrm{~mL} / \mathrm{min}$ (Bronkhorst F-231M flow controller). The injection pressure of Pearson water was $0.1 \mathrm{MPa}$ and increased to $0.3 \mathrm{MPa}$ after 4 days. After 543 days, the fluid inlet was closed and the experiments were run for another 142 days. During saturation, the development of the swelling pressure and the fluid volume balance (in- and outflow) were monitored and the stationary fluid permeability was calculated. After saturation and development of steady-state flow conditions, the outflow fluid was collected to determine its ion content for studying ion transport and cation exchange processes. Both columns were dismantled after 685 days and analyzed for water content and chemical/mineralogical changes.

\subsection{Methods}

\subsubsection{Sampling}

Immediately after unloading of the oedometer cells the upper pistons and filter plates were removed. In a stepwise dismantling procedure from top to bottom, each of the different sandwich segments was uncovered and probed. In both experiments, the upper filter plates were found to be nearly saturated with the fluid. Two samples were taken in each segment, one for determination of the water content (about 50-100 g each) and the other one for determination of the chemical and mineralogical composition/changes (about $50 \mathrm{~g}$ of each ES and about $250 \mathrm{~g}$ of each DS). Samples for determination of water content were immediately placed in the oven after initial weighing. Samples for chemical and mineralogical analyses were shrink-wrapped in foil until further analysis.

The fabric of the dismantled DS in both cells was still characterized by recognizable bentonite granules and fine sand grains. The following analyses were performed with homogenized material and separated bentonite granules were studied if additional information was expected. 


\subsubsection{Water Content}

The water content and moisture of the materials were determined mostly in duplicate after heating at $105{ }^{\circ} \mathrm{C}$ and $200{ }^{\circ} \mathrm{C}$ for $24 \mathrm{~h}$ or until constant weight $(\Delta \mathrm{m}<0.1 \%)$ was obtained [19]. Heating to $200^{\circ} \mathrm{C}$ is necessary to dehydrate swellable clay minerals [20] in bentonites. The water content was calculated with respect to dry mass of the sample after heating, while moisture was calculated in relation to the initial mass of the sample.

\subsubsection{X-ray Diffraction Analysis (XRD)}

Mineralogical quantification of Secursol UHP was performed by X-ray diffraction (XRD) measurements on powder samples $<500 \mu \mathrm{m}$. Samples were milled using the McCrone Micronizing mill with zirconium oxide cylindrical grinding elements (McCrone Microscopes and Accessories, Westmont, IL, USA). A Bruker D8 Advance A25 diffractometer (Bruker AXS GmbH, Karlsruhe, Germany) equipped with a LYNXEYE XE Detector (opening degree $2.94^{\circ}$ and 192 channels) was used. Patterns were recorded between 2 and $80^{\circ} 2 \theta$ with $\mathrm{CuK} \alpha$ radiation, a counting time of $2 \mathrm{~s}$ and a step size of $0.02^{\circ} 2 \theta$, a fixed slit of $0.18^{\circ}$, Soller collimator of $2.5^{\circ}$ (primary and secondary side) and an automatic knife edge for powder samples. Rietveld software PROFEX 4.3.2 (Nicola Döbelin, Solothurn, Switzerland) was utilized for quantitative analysis [21]. Quantitative phase content was converted in chemical composition and compared with chemical composition from X-ray fluorescence analysis (Supplementary Materials).

2.2.4. Cation Exchange Capacity (CEC), Exchangeable Cations (EC) and Cations in Pearson Water and Outflow Liquid

CEC was measured by the modified Cu-trien method according to Meier and Kahr [22]. Approximately $50 \mathrm{mg}$ of ground sample were dispersed in a $15 \mathrm{~mL}$ centrifuge tube after adding $10 \mathrm{~mL}$ of Millipore water and $5 \mathrm{~mL}$ of a copper-triethylenetetramine (Cu-trien) solution of $0.01 \mathrm{~mol} / \mathrm{L}$ by shaking for $3 \mathrm{~h}$ on a vibrating table. After centrifugation at $4500 \mathrm{rpm}$ for $10 \mathrm{~min}$ (Multifuge 3S-R, Heraeus Holding GmbH, Hanau, Germany), the absorbance of the supernatants was measured at a wavelength $(\lambda)$ of $580 \mathrm{~nm}$ with a UV-Vis spectrophotometer (Genesys 10 UV, Thermo Electron Corporation, Waltham, MA, USA) using polystyrene microcuvettes (Lab logistics Groups $\mathrm{GmbH}$, Meckenheim, Germany) with a path length of $1 \mathrm{~cm}$. The concentrations of $\mathrm{Cu}$-trien in the supernatants were determined from a calibration curve and CEC $[\mathrm{cmol}(+) / \mathrm{kg}]$ was calculated on the basis of the depletion of the supernatant by uptake of $\mathrm{Cu}$-Trien by the smectite. The concentrations of exchangeable cations were analyzed from supernatant after dilution (if required) and acidification with $\mathrm{HNO}_{3}$ (1M Suprapur) by inductively-coupled plasma-optical emission spectrometry (ICP-OES) (Optima 8300 DV, Perkin Elmer Inc., Waltham, MA, USA). Cations in Pearson water and outflow liquid were measured in the same way by ICP-OES.

2.2.5. Aqueous Leachate/Soluble Ions and Anions in Pearson Water and Outflow Liquid

Approximately $2 \mathrm{~g}$ of the sample were weighed into $50 \mathrm{~mL}$ centrifuge tube and dispersed in $40 \mathrm{~mL}$ of Millipore water by shaking for $24 \mathrm{~h}$ on a vibrating table. Thereafter, the samples were centrifuged at $4500 \mathrm{rpm}$ for $10 \mathrm{~min}$. Conductivity and temperature were measured in the supernatant using conductometer WTW LF 318 (Xylem Analytics Germany Sales $\mathrm{GmbH}$ and Co. KG, Weilheim in Oberbayern, Germany). The $\mathrm{pH}$ was measured with $\mathrm{pH}$ strips (Merck, $\mathrm{pH}$ 4.0-7.0 Special indicator).

The supernatant was filtered through a $0.45 \mu \mathrm{m}$ filter (syringe filter, cellulose acetate, $\mathrm{d}=25 \mathrm{~mm}$, LLG-Labware GmbH, Meckenheim, Germany). Cations were analyzed by ICP-OES method and anions by ionic chromatography (Dionex Aquion IC System with Autosampler by Thermo Fisher Scientific GmbH, Dreieich, Germany). Anions in Pearson water and outflow liquid were measured in the same way by IC. 


\section{Results}

\subsection{Geotechnical Parameters}

Both cells were installed with identical dry densities and thus resulting porosity (Table 3). Due to the different hydration state and water content of the DS material $5.3 \%$ of the total porosity and $7.7 \%$ of the porosity of both DS in cell 9 were filled with water, while $21.7 \%$ of the total porosity and $31.5 \%$ of the porosity of both DS in cell 10 were already filled with water after installation.

Right at the start of the hydration/re-saturation $44.2 \mathrm{~mL}$ of liquid entered cell 9, and $45.4 \mathrm{~mL}$ liquid went into cell 10 within 5 min of starting the hydration. Thereby, ES1 in both cells were saturated. Fluid uptake and inflow permeability decreased strongly in both cells (Figures 2 and 3) until a fast breakthrough after $14 \mathrm{~d}$ was observed for both cells. The fluid breakthrough in cell 9 occurred after a fluid uptake (difference inflow/outflow fluid volume) of $359 \mathrm{~mL}$, that corresponded to a saturation of $94.5 \%$. The breakthrough in cell 10 was accompanied with a fluid uptake of $309 \mathrm{~mL}$ corresponding to a saturation of $98 \%$. Actual fluid uptake was $4.5 \%$ and $2.5 \%$ higher than calculated (Tables 3 and 5). After the breakthrough $4289 \mathrm{~mL}$ and $2984 \mathrm{~mL}$, respectively, Pearson water passed the outflow of cell 9 and 10 until termination of the experiment.

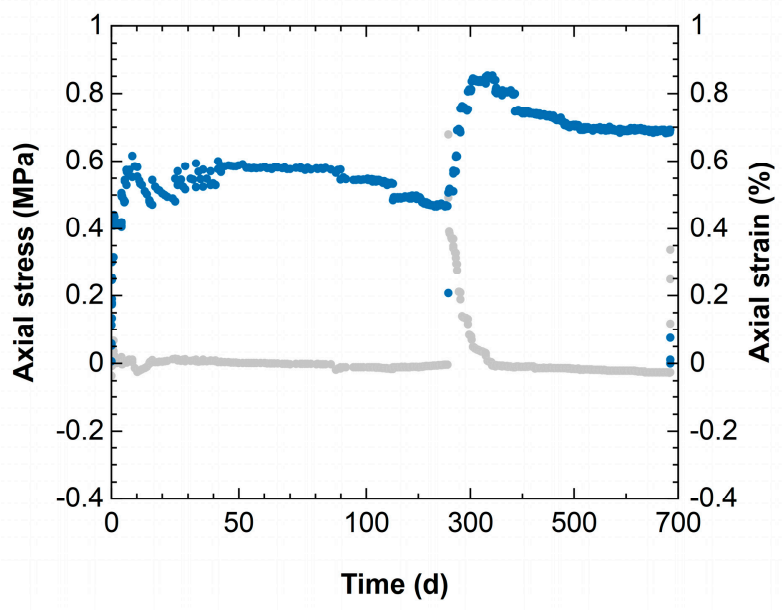

(a)

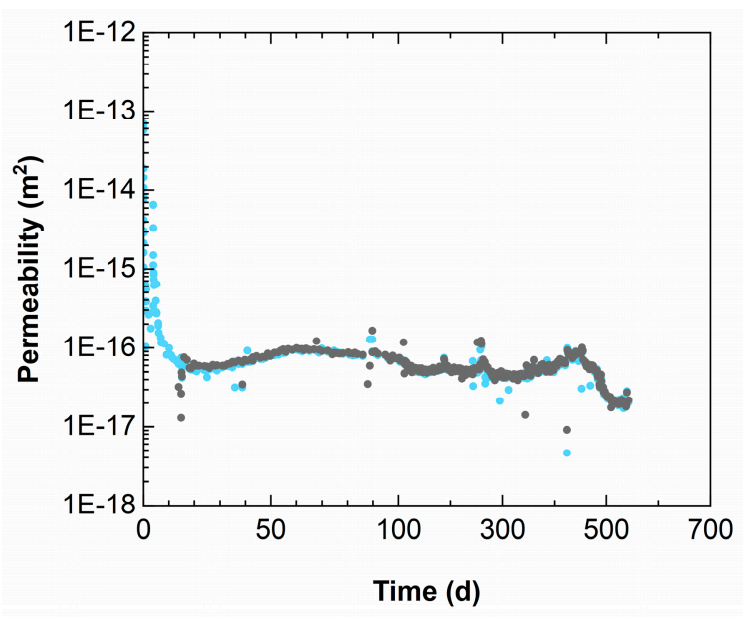

(b)

Figure 2. (a) Axial strain (grey) and axial stress (blue) and (b) inflow (blue) and outflow (grey) permeability cell 9.

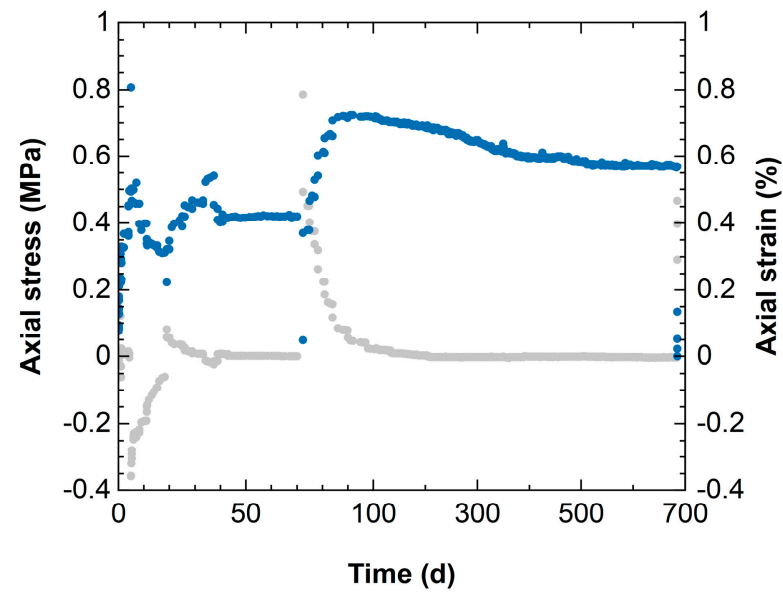

(a)

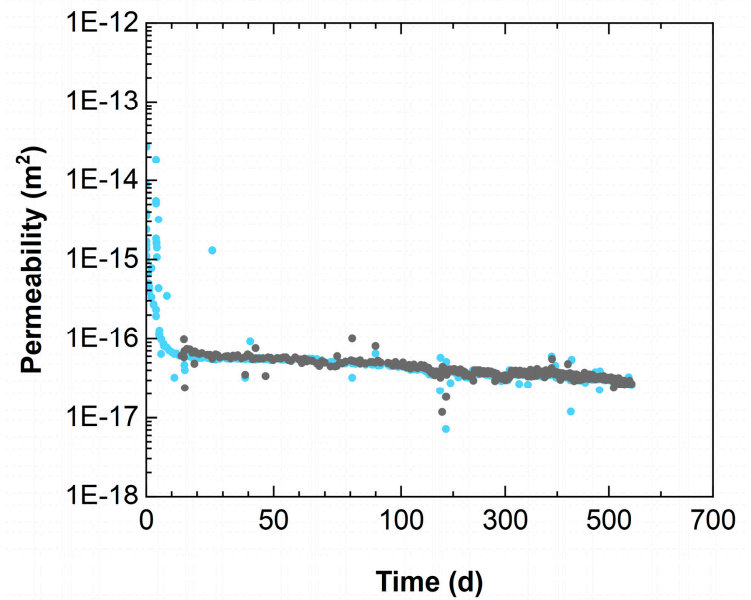

(b)

Figure 3. (a) Axial strain (grey) and axial stress (blue) and (b) inflow (blue) and outflow (grey) permeability cell 10. 
Table 5. Water content $\left(200^{\circ} \mathrm{C}\right)\left(\mathrm{w}_{\mathrm{e}}\right)$, volume of water $\left(\mathrm{V}_{\mathrm{W}}\right)$, dry density and volume (height) change after dismantling of cell 9 and 10 .

\begin{tabular}{ccccc}
\hline & $\mathbf{w}_{\mathbf{e}}$ & $\mathbf{V}_{\mathbf{w}}$ & $\boldsymbol{\rho}_{\mathbf{d}}$ & $\Delta \mathbf{V}$ or $\Delta \mathbf{h}$ \\
\cline { 2 - 5 } Cell 9 & {$[\%]$} & {$[\mathbf{m L}]$} & {$\left[\mathbf{g} / \mathbf{c m}^{\mathbf{3}}\right]$} & {$[\%]$} \\
\hline ES3 & 22.81 & 36.2 & 1.66 & -6.5 \\
DS2 & 44.15 & 153.0 & 1.25 & 3.7 \\
ES2 & 22.81 & 36.2 & 1.66 & -6.5 \\
DS1 & 44.65 & 154.8 & 1.24 & 6.6 \\
ES1 & 24.77 & 39.3 & 1.61 & -3.2 \\
sum & & 419.6 & & $\Delta \mathbf{V}$ or $\Delta \mathbf{h}$ \\
\hline & & $\mathbf{V}_{\mathbf{w}}$ & $\rho_{\mathbf{d}}$ & {$[\%]$} \\
Cell 10 & $\mathbf{w}_{\mathbf{e}}$ & {$[\mathbf{m L}]$} & {$\left[\mathbf{g} / \mathbf{c m}^{3}\right]$} & -7.5 \\
& {$[\%]$} & 35.3 & 1.68 & -0.4 \\
ES3 & 22.25 & 141.9 & 1.26 & 7.0 \\
DS2 & 43.27 & 37.8 & 1.64 & -2.6 \\
ES2 & 23.78 & 155.8 & 1.24 & \\
DS1 & 44.94 & 39.9 & 1.60 & \\
ES1 & 25.12 & 410.7 & & \\
sum & & &
\end{tabular}

Inflow permeability was higher in cell 9 than in cell 10 until breakthrough. Afterwards hydraulic permeability decreased very slowly to $2-2.7 \times 10^{-17} \mathrm{~m}^{2}$ until the experiment was terminated (Figures 2 and 3).

A pressure loss in the hydraulic storage medium and thus a power loss in the hydraulic cylinder that ensures the constant volume of the MiniSandwich occurred in cell 9 at day 258 and in cell 10 at day 72 which resulted in free swelling of the MiniSandwich. After compensation of the pressure loss the volume was constant again (axial strain $0 \%$ ) and an increased swelling pressure was observed, which decreased only slightly during 200-250 d until it was close to constant in both cells. The total axial stress was slightly higher in cell 9 than in cell 10 (Table 4). Despite of the diameter/height ratio of 1:1.5 friction effects of the material at the cell walls were negligible because of the limited axial displacement (volume constancy). Thus, the measured total axial stress corresponds to the overall swelling pressure.

\subsection{Volume Changes Due to Swelling of DS}

Under the assumption of full saturation, the volume change and change in dry density of each DS and ES were calculated from the water content during dismantling (Table 5). DS in cell 9 and cell 10 expanded up to 7\%, while expansion was equal in DS1 and DS2 of cell 9 and only DS1 expanded in cell 10. Thereby, the fine sand in all ES was compacted to a dry density of $1.66 \mathrm{~g} / \mathrm{cm}^{3}$ which is slightly above its measured $\rho_{\mathrm{d} \text {,max }}\left(1.644 \mathrm{~g} / \mathrm{cm}^{3}\right)$ and in the range of measurement uncertainty.

\subsection{Cation Exchange Capacity (CEC) and Exchangeable Cations (EC)}

Secursol UHP is a Ca,Mg-bentonite with a CEC of $93 \mathrm{cmol}(+) / \mathrm{kg}$ (Table 6). By blending the bentonite the smectite content in DS was $58.6 \%$ and the CEC of the DS material was $73 \mathrm{cmol}(+) / \mathrm{kg}$. The apparent $\mathrm{pH}$ of dispersed Secursol UHP was 4.7. After dismantling, a slightly lower average CEC was measured in DS of cell 9 and cell 10 (Table 7), but deviation is in the range of measurement uncertainty. The exchangeable $\mathrm{Na}^{+}$strongly increased from 0.7 to $24-29 \mathrm{cmol}(+) / \mathrm{kg}$ while exchangeable $\mathrm{Ca}^{2+}$ decreased by about $1 / 3$ from 42 to $25-30 \mathrm{cmol}(+) / \mathrm{kg}$ with lower values in DS1 of cell 9 and cell 10. Exchangeable $\mathrm{Mg}^{2+}$ was nearly constant in DS of both cells compared to the initial $\mathrm{Mg}^{2+}$ of the installed bentonite blend. Exchangeable $\mathrm{K}^{+}$was very low in DS of both cells but increased slightly. Exchangeable $\mathrm{Fe}^{3+}$ was slightly higher in DS1 of cell 10 but in any other DS was close to 
the value of the initial blend. Sum of exchangeable cations now equaled the measured CEC (Table 7).

Table 6. CEC, exchangeable cations, conductivity of suspension and soluble cations and anions of Secursol UHP (granular material HTV-6 [5]).

\begin{tabular}{|c|c|c|c|c|c|c|c|c|}
\hline CEC & $\mathrm{Na}^{+}$ & $\mathrm{Ca}^{2+}$ & $\mathrm{Mg}^{2+}$ & $\mathrm{K}^{+}$ & $\mathrm{Fe}^{3+}$ & Sum & $\mathrm{Cl}^{-}$ & $\mathrm{SO}_{4}{ }^{2-}$ \\
\hline \multicolumn{7}{|c|}{$[\mathrm{cmol}(+) / \mathrm{kg}]$} & \multicolumn{2}{|c|}{ [cmol(-)/kg] } \\
\hline \multirow{3}{*}{93} & 0.9 & 54 & 19 & 1.3 & 0.03 & 75 & - & - \\
\hline & {$[\mathrm{mg} / \mathrm{g}]$} & {$[\mathrm{mg} / \mathrm{g}]$} & {$[\mathrm{mg} / \mathrm{g}]$} & {$[\mathrm{mg} / \mathrm{g}]$} & {$[\mathrm{mg} / \mathrm{g}]$} & {$[\mathrm{mg} / \mathrm{g}]$} & {$[\mathrm{mg} / \mathrm{g}]$} & {$[\mathrm{mg} / \mathrm{g}]$} \\
\hline & 0.2 & 12.9 & 2.8 & 0.6 & 0.01 & 17 & - & - \\
\hline \multirow{2}{*}{$\begin{array}{l}\text { Conductivity } \\
\qquad \mu \mathrm{S} / \mathrm{cm}]\end{array}$} & $\mathrm{Na}^{+}$ & $\mathrm{Ca}^{2+}$ & $\mathrm{Mg}^{2+}$ & $\mathrm{K}^{+}$ & $\mathrm{Fe}^{3+}$ & Sum & $\mathrm{Cl}^{-}$ & $\mathrm{SO}_{4}{ }^{2-}$ \\
\hline & \multicolumn{6}{|c|}{$[\mathrm{cmol}(+) / \mathrm{kg}]$} & \multicolumn{2}{|c|}{$[\mathrm{cmol}(-) / \mathrm{kg}]$} \\
\hline \multirow{3}{*}{36.8} & 0.34 & 1.11 & 0.81 & 0.14 & 0.83 & 3.2 & 0.2 & 0.3 \\
\hline & {$[\mathrm{mg} / \mathrm{g}]$} & {$[\mathrm{mg} / \mathrm{g}]$} & {$[\mathrm{mg} / \mathrm{g}]$} & {$[\mathrm{mg} / \mathrm{g}]$} & {$[\mathrm{mg} / \mathrm{g}]$} & {$[\mathrm{mg} / \mathrm{g}]$} & {$[\mathrm{mg} / \mathrm{g}]$} & {$[\mathrm{mg} / \mathrm{g}]$} \\
\hline & 0.08 & 0.22 & 0.10 & 0.05 & 0.15 & 0.6 & 0.05 & 0.13 \\
\hline
\end{tabular}

Table 7. CEC, exchangeable cations, electric conductivity of supernatant suspension and soluble cations and anions (granular material HTV-6 [5]).

\begin{tabular}{|c|c|c|c|c|c|c|c|c|c|c|}
\hline & & CEC & $\mathrm{Na}^{+}$ & $\mathrm{Ca}^{2+}$ & $\mathrm{Mg}^{2+}$ & $\mathbf{K}^{+}$ & $\mathrm{Fe}^{3+}$ & Sum & & \\
\hline & & \multicolumn{3}{|c|}{$[\mathrm{cmol}(+) / \mathrm{kg}]$} & \multicolumn{3}{|c|}{$[\mathrm{cmol}(+) / \mathrm{kg}]$} & & & \\
\hline Blend * & & 73 & 0.7 & 42 & 15 & 1.0 & 0.02 & 59 & & \\
\hline \multirow[b]{2}{*}{ Cell 9} & DS2 & 74 & 29 & 30 & 14 & 1.7 & 0.01 & 75 & & \\
\hline & DS1 & 70 & 28 & 25 & 14 & 2.0 & 0.01 & 69 & & \\
\hline \multirow{4}{*}{ Cell 10} & DS2 & 71 & 24 & 30 & 12 & 1.3 & 0.03 & 67 & & \\
\hline & DS1 & 70 & 25 & 27 & 14 & 1.9 & 0.06 & 69 & & \\
\hline & & \multicolumn{2}{|c|}{ ConductivityNa } & $\mathrm{Ca}$ & $\mathrm{Mg}$ & $\mathbf{K}$ & $\mathrm{Fe}$ & Sum * & $\mathrm{Cl}^{-}$ & $\mathrm{SO}_{4}{ }^{2-}$ \\
\hline & & \multicolumn{3}{|c|}{$[\mathrm{mS} / \mathrm{cm}]$} & \multicolumn{3}{|c|}{$[\mathrm{cmol}(+) / \mathrm{kg}]$} & & \multicolumn{2}{|c|}{$[\mathrm{cmol}(-) / \mathrm{kg}]$} \\
\hline Blend * & & 0.0287 & 0.3 & 0.9 & 0.6 & 0.1 & 0.7 & 2.6 & 0.16 & 0.23 \\
\hline \multirow{2}{*}{ Cell 9} & DS2 & & 14 & 7 & 4 & 0.7 & 0.1 & 25 & 2.6 & 4.1 \\
\hline & DS1 & & 15 & 7 & 5 & 0.8 & 0.1 & 27 & 2.9 & 4.2 \\
\hline \multirow{2}{*}{ Cell 10} & DS2 & & 11 & 5 & 3 & 0.5 & 0.2 & 20 & 2.5 & 4.3 \\
\hline & DS1 & & 14 & 7 & 5 & 0.8 & 0.2 & 26 & 2.3 & 3.5 \\
\hline
\end{tabular}

Note: * calculated.

\subsection{Cations in Outflow and Soluble Cations (SC)}

Sodium concentration in the outflow of both cells increased with a steep linear slope during the first 100 days. Afterwards, the Na concentration increased further with a linear but less steep slope up to 200 days (cell 9) and 300 days (cell 10), respectively, until it reached a nearly constant value of about 157 and $150 \mathrm{mmol} / \mathrm{L}$ (Figures 4 and 5) corresponding to the inflow concentration. For cell 10 a slight decrease in Na concentration was observed around day 100 and 300 of the experiment at the beginning of each change in slope of outflow concentration (Figure 5). The concentration of $\mathrm{Ca}, \mathrm{Mg}$ and $\mathrm{K}$ decreased potentially $\left(x^{-1 / 2}\right)$ approaching asymptotically a concentration close to the concentration of each cation in the inflow Pearson water (Figures 4 and 5). Thereby the calcium concentration was 16 and $20 \mathrm{mmol} / \mathrm{L}$ for cell 9 and 10, respectively, and thus slightly higher than $11.6 \mathrm{mmol} / \mathrm{L}$ in the inflow. The asymptotic concentrations of $\mathrm{Mg}$ and $\mathrm{K}$ were $7.2 / 8.7 \mathrm{mmol} / \mathrm{L}$ and $1.6 / 1.5 \mathrm{mmol} / \mathrm{L}$, respectively, for cell 9 and 10 . 
The cumulative amount of $\mathrm{Na}$ in the volume of Pearson water that passed the MiniSandwich cells was 1.29 (cell 9) and 0.93 (cell 10) times of the initial CEC of the DS and the cumulative amount of $\mathrm{Na}$ in the outflow amounted 1.15 and 0.74 times the initial CEC of the DS, respectively, in cell 9 and cell 10. Corresponding values were $0.20 / 0.14$ and $0.48 / 0.40(\mathrm{Ca}), 0.15 / 0.11$ and $0.20 / 0.16(\mathrm{Mg})$ and $0.02 / 0.02$ and $0.01 / 0.01(\mathrm{~K})$. The resulting ratio of cations in the outflow to cation input into each MiniSandwich (cell 9/cell 10) to was $0.89 / 0.80(\mathrm{Na}), 2.44 / 2.88(\mathrm{Ca}), 1.36 / 1.50(\mathrm{Mg})$ and $0.54 / 0.52(\mathrm{~K})$.

After dismantling, in ES of both cells 56-104\% of the expected soluble Na was found with lowest values in the outer ES1 and ES3 of cell 9 and highest values in the outer ES1 and ES3 of cell 10. Both $\mathrm{Ca}$ and $\mathrm{Mg}$ showed a similar distribution pattern in ES of both cells (Table 8 ). In contrast, less than $56 \%$ of expected soluble $\mathrm{K}$ was found after dismantling in ES of both cells, but, again, the distribution pattern was the same as for the other cations. No soluble $\mathrm{Fe}^{3+}$ was measured in ES of both cells.

(a)

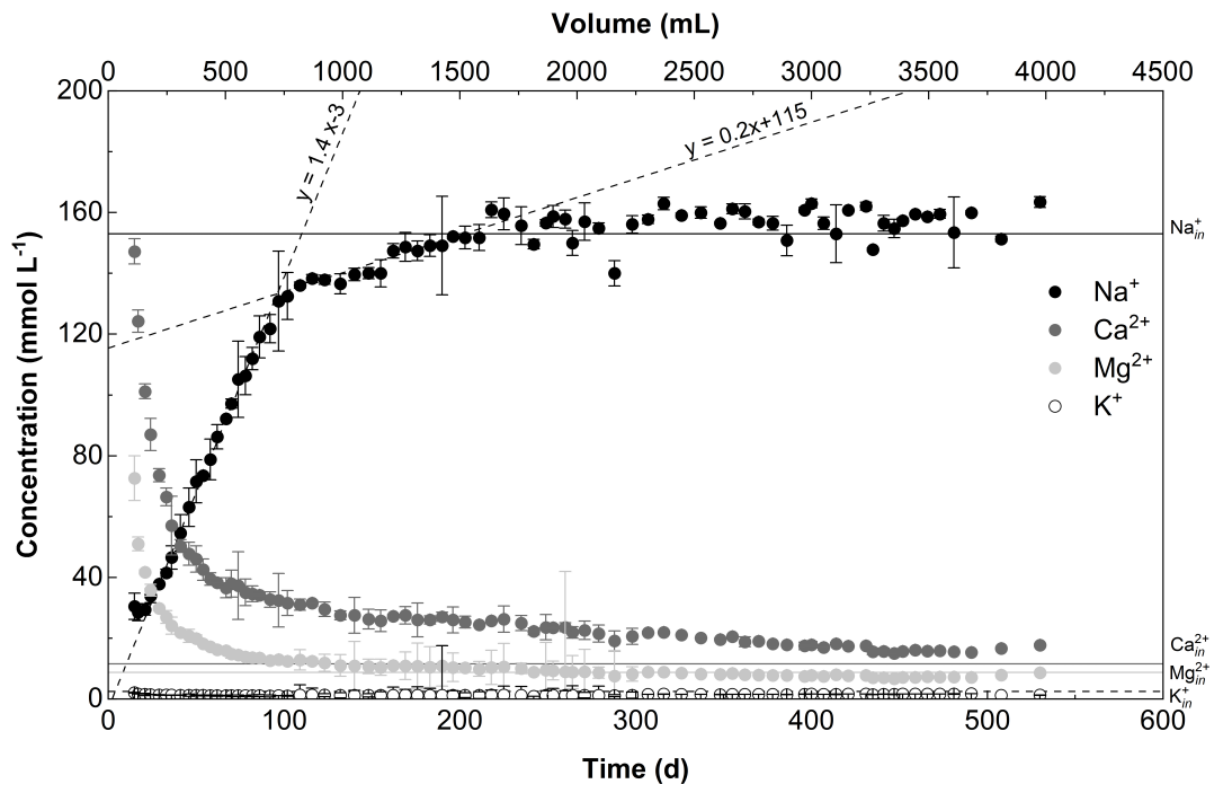

(b)

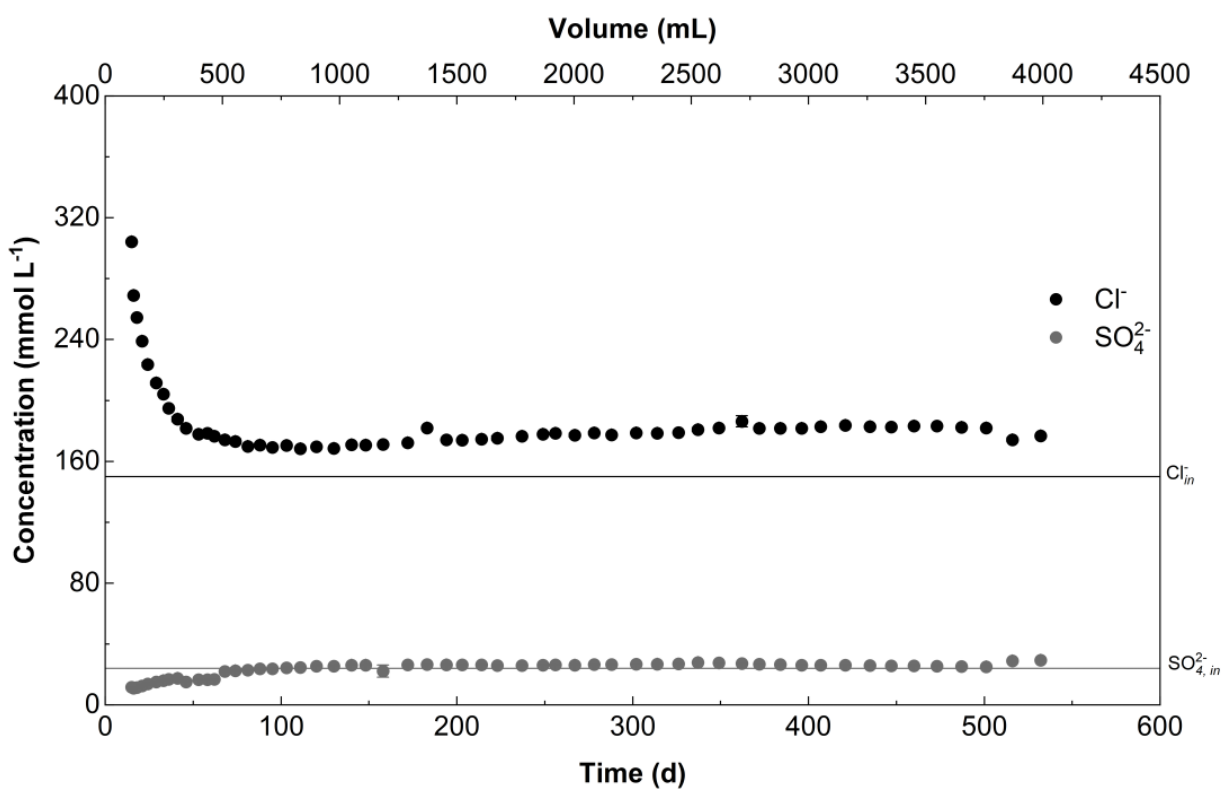

Figure 4. Cation concentration (a) and anion concentration in outflow (b) of cell 9. 
(a)

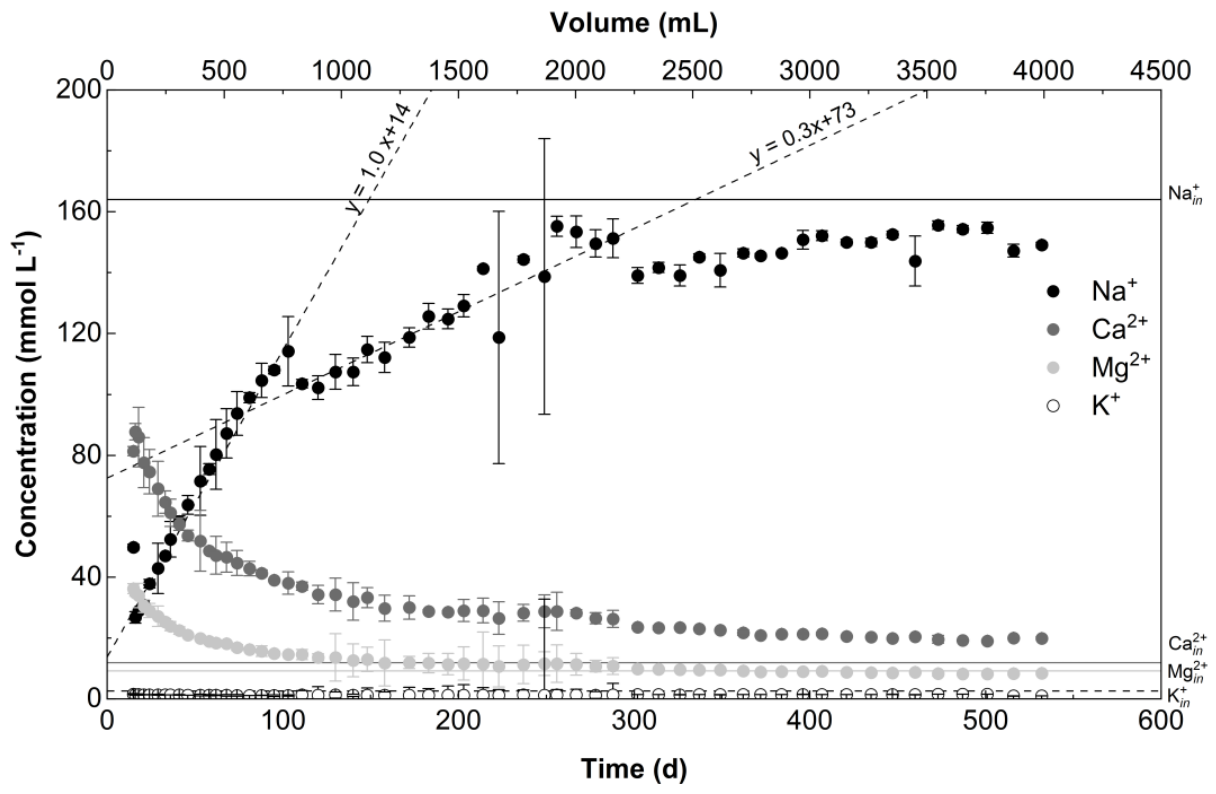

(b)

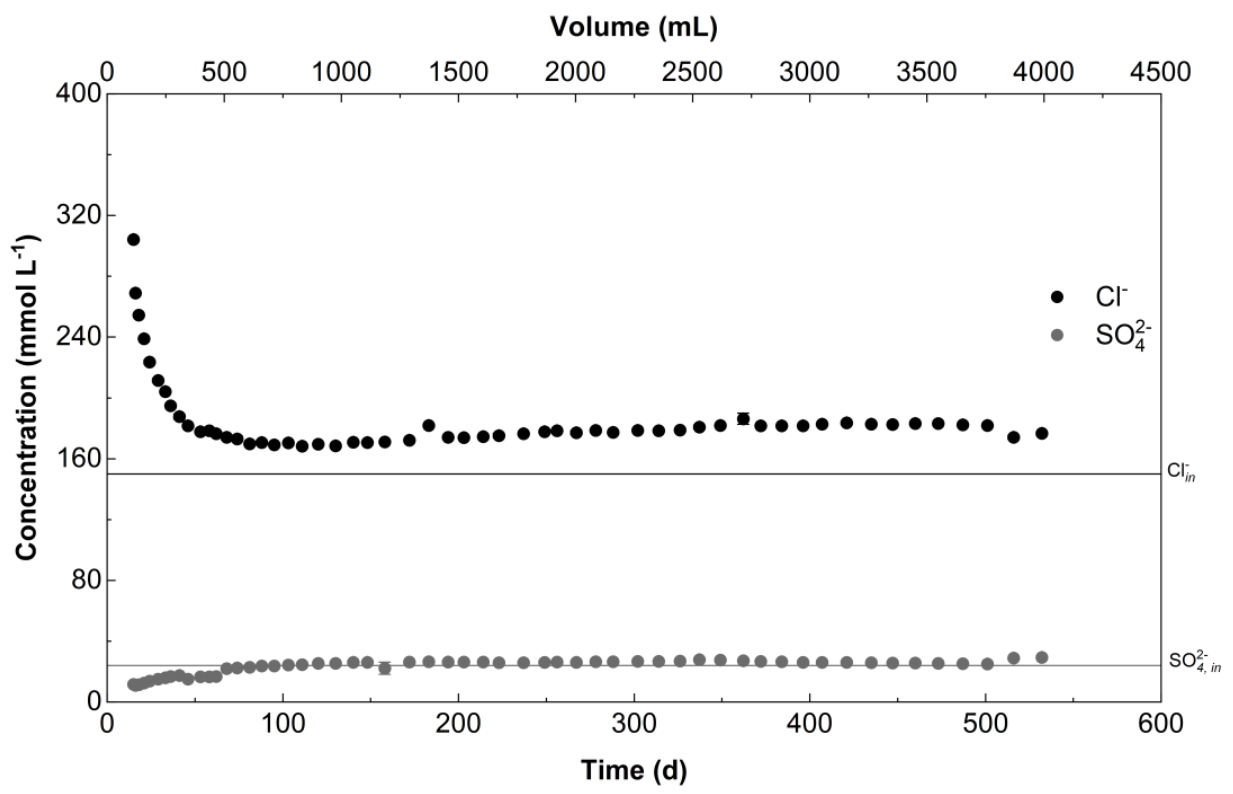

Figure 5. Cation concentration (a) and anion concentration in outflow (b) of cell 10.

In contrast the soluble $\mathrm{Na}$ in the DS of both cells was twice as high as expected and the concentrations of soluble $\mathrm{Ca}, \mathrm{Mg}$ and $\mathrm{K}$ were five to seven times higher than expected from water content (Table 8). About 0.02 to $0.04 \mathrm{mg} / \mathrm{g}$ Fe were found in DS of both cells. The molar ratio of soluble cations to soluble anions was about 3.7 (Table 7) in DS of both cells while it was about 6.4 in the raw Secursol UHP (Table 6) and 0.64-0.82 in the ES of both cells after dismantling. 
Table 8. Cation concentration in DS and ES after dismantling.

\begin{tabular}{|c|c|c|c|c|c|c|c|c|c|c|c|c|c|c|}
\hline Cell 9 & $\begin{array}{c}1 \\
\mathrm{Na} \\
{[\mathrm{mg} / \mathrm{g}]}\end{array}$ & $\begin{array}{c}2 \\
\mathrm{Ca} \\
{[\mathrm{mg} / \mathrm{g}]}\end{array}$ & $\begin{array}{c}3 \\
\mathrm{Mg} \\
{[\mathrm{mg} / \mathrm{g}]}\end{array}$ & $\begin{array}{c}4 \\
\mathrm{~K} \\
{[\mathrm{mg} / \mathrm{g}]} \\
\end{array}$ & $\begin{array}{c}5 \\
\mathrm{Fe} \\
{[\mathrm{mg} / \mathrm{g}]}\end{array}$ & $\begin{array}{c}6 \\
\mathrm{Na} \\
{[\mathrm{mg} / \mathrm{g}]}\end{array}$ & $\begin{array}{c}7 \\
\mathrm{Ca} \\
{[\mathrm{mg} / \mathrm{g}]}\end{array}$ & $\begin{array}{c}8 \\
\mathrm{Mg} \\
{[\mathrm{mg} / \mathrm{g}]}\end{array}$ & $\begin{array}{c}9 \\
\mathrm{~K} \\
{[\mathrm{mg} / \mathrm{g}]}\end{array}$ & $\begin{array}{c}10 \\
\mathrm{Fe} \\
{[\mathrm{mg} / \mathrm{g}]}\end{array}$ & $\begin{array}{c}11 \\
\mathrm{Na} \\
\mathrm{c1}: \mathrm{c6}\end{array}$ & $\begin{array}{c}12 \\
\mathrm{Ca} \\
\text { c2:c7 }\end{array}$ & $\begin{array}{c}13 \\
\mathrm{Mg} \\
\mathrm{c} 3: \mathrm{c} 8\end{array}$ & $\begin{array}{c}14 \\
\mathrm{~K} \\
\mathrm{c4}: \mathrm{c} 9\end{array}$ \\
\hline ES3 & 0.698 & 0.096 & 0.036 & 0.010 & 0.000 & 0.804 & 0.106 & 0.048 & 0.022 & 0.00 & 0.87 & 0.90 & 0.74 & 0.46 \\
\hline DS2 & 3.182 & 1.339 & 0.496 & 0.281 & 0.022 & 1.556 & 0.206 & 0.094 & 0.043 & 0.00 & 2.04 & 6.51 & 5.30 & 6.50 \\
\hline ES2 & 0.837 & 0.114 & 0.042 & 0.012 & 0.000 & 0.804 & 0.106 & 0.048 & 0.022 & 0.00 & 1.04 & 1.07 & 0.87 & 0.56 \\
\hline DS1 & 3.384 & 1.310 & 0.564 & 0.311 & 0.023 & 1.574 & 0.208 & 0.095 & 0.044 & 0.00 & 2.15 & 6.30 & 5.96 & 7.12 \\
\hline ES1 & 0.842 & 0.102 & 0.044 & 0.013 & 0.000 & 0.873 & 0.115 & 0.052 & 0.024 & 0.00 & 0.96 & 0.88 & 0.84 & 0.55 \\
\hline Cell 10 & $\begin{array}{c}\mathrm{Na} \\
{[\mathrm{mg} / \mathrm{g}]}\end{array}$ & $\begin{array}{c}\text { Ca } \\
{[\mathrm{mg} / \mathrm{g}]}\end{array}$ & $\begin{array}{c}\mathrm{Mg} \\
{[\mathrm{mg} / \mathrm{g}]}\end{array}$ & $\begin{array}{c}\mathrm{K} \\
{[\mathrm{mg} / \mathrm{g}]} \\
\end{array}$ & $\begin{array}{c}\mathrm{Fe} \\
{[\mathrm{mg} / \mathrm{g}]}\end{array}$ & $\begin{array}{c}\mathrm{Na} \\
{[\mathrm{mg} / \mathrm{g}]}\end{array}$ & $\begin{array}{c}\mathrm{Ca} \\
{[\mathrm{mg} / \mathrm{g}]}\end{array}$ & $\begin{array}{c}\mathrm{Mg} \\
{[\mathrm{mg} / \mathrm{g}]}\end{array}$ & $\begin{array}{c}\mathrm{K} \\
{[\mathrm{mg} / \mathrm{g}]}\end{array}$ & $\begin{array}{c}\mathrm{Fe} \\
{[\mathrm{mg} / \mathrm{g}]}\end{array}$ & $\begin{array}{c}\mathrm{Na} \\
\mathrm{c1}: \mathrm{c6}\end{array}$ & $\begin{array}{c}\mathrm{Ca} \\
\mathrm{c} 2: \mathrm{c} 7\end{array}$ & $\begin{array}{c}\mathrm{Mg} \\
\mathrm{c3}: \mathrm{c8}\end{array}$ & $\begin{array}{c}\mathrm{K} \\
\mathrm{c} 4: \mathrm{c} 9\end{array}$ \\
\hline ES3 & 0.695 & 0.132 & 0.034 & 0.008 & 0.000 & 0.784 & 0.104 & 0.047 & 0.022 & 0.00 & 0.89 & 1.27 & 0.73 & 0.36 \\
\hline DS2 & 2.619 & 1.011 & 0.356 & 0.213 & 0.040 & 1.525 & 0.202 & 0.092 & 0.042 & 0.00 & 1.72 & 5.02 & 3.89 & 5.03 \\
\hline ES2 & 0.469 & 0.071 & 0.026 & 0.007 & 0.004 & 0.838 & 0.111 & 0.050 & 0.023 & 0.00 & 0.56 & 0.64 & 0.52 & 0.31 \\
\hline DS1 & 3.191 & 1.373 & 0.576 & 0.300 & 0.030 & 1.584 & 0.209 & 0.095 & 0.044 & 0.00 & 2.01 & 6.56 & 6.05 & 6.81 \\
\hline ES1 & 0.790 & 0.106 & 0.040 & 0.012 & 0.000 & 0.885 & 0.117 & 0.053 & 0.025 & 0.00 & 0.89 & 0.91 & 0.76 & 0.49 \\
\hline
\end{tabular}

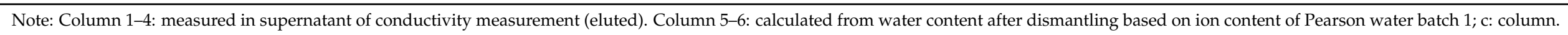




\subsection{Anions in Outflow and Soluble Anions (SA)}

The $\mathrm{Cl}^{-} / \mathrm{SO}_{4}{ }^{2-}$ weight ratio was 2.31 (molar ratio 6.25, Table 2) in the inflow Pearson water and 2.55 (molar ratio 6.9) in the outflow of cell 9 and 2.66 (molar ratio 7.2) in the outflow of cell 10 (Figures 4 and 5). In contrast, the $\mathrm{Cl}^{-} / \mathrm{SO}_{4}{ }^{2-}$ weight ratio in the DS was $0.51 / 0.47$ in cell 9 and $0.50 / 0.43$ in cell 10 (Table 9). In ES the $\mathrm{Cl}^{-} / \mathrm{SO}_{4}{ }^{2-}$ weight ratio varied between 0.42 and 0.69 with the lowest ratio in ES3 of cell 9 and ES2 in cell 10 and the highest ratio in ES1 of both cells (Table 9). Thereby, the $\mathrm{SO}_{4}{ }^{2-}$ concentration was significantly higher than expected from water content and $\mathrm{SO}_{4}{ }^{2-}$ concentration in the Pearson water while the $\mathrm{Cl}^{-}$concentration was only about $39-77 \%$ of the expected concentration in DS of both cells (Table 9).

Table 9. Anion concentration in DS and ES after dismantling.

\begin{tabular}{|c|c|c|c|c|c|c|c|c|c|}
\hline & 1 & 2 & 3 & 4 & 5 & 6 & 7 & 8 & 9 \\
\hline Cell 9 & $\begin{array}{c}\mathrm{Cl}^{-} \\
{[\mathrm{mg} / \mathrm{g}]}\end{array}$ & $\begin{array}{l}\mathrm{SO}_{4}^{2-} \\
{[\mathrm{mg} / \mathrm{g}]}\end{array}$ & $\begin{array}{c}\text { sum } \\
{[\mathrm{mg} / \mathrm{g}]}\end{array}$ & c1:c2 & $\begin{array}{c}\mathrm{Cl}^{-} \\
{[\mathrm{mg} / \mathrm{g}]}\end{array}$ & $\begin{array}{l}\mathrm{SO}_{4}{ }^{2-} \\
{[\mathrm{mg} / \mathrm{g}]}\end{array}$ & $\begin{array}{l}\text { Sum } \\
{[\mathrm{mg} / \mathrm{g}]}\end{array}$ & c1:c5 & c2:c6 \\
\hline ES3 & 0.78 & 1.32 & 2.10 & 0.59 & 1.22 & 0.53 & 1.74 & 0.64 & 2.51 \\
\hline DS2 & 0.93 & 1.97 & 2.89 & 0.47 & 2.35 & 1.02 & 3.37 & 0.39 & 1.93 \\
\hline ES2 & 0.93 & 1.41 & 2.34 & 0.66 & 1.22 & 0.53 & 1.74 & 0.77 & 2.67 \\
\hline DS1 & 1.01 & 2.01 & 3.02 & 0.51 & 2.38 & 1.03 & 3.41 & 0.43 & 1.94 \\
\hline ES1 & 0.96 & 1.39 & 2.36 & 0.69 & 1.32 & 0.57 & 1.89 & 0.73 & 2.44 \\
\hline Cell 10 & $\begin{array}{c}\mathrm{Cl}^{-} \\
{[\mathrm{mg} / \mathrm{g}]}\end{array}$ & $\begin{array}{l}\mathrm{SO}_{4}{ }^{2-} \\
{[\mathrm{mg} / \mathrm{g}]}\end{array}$ & $\begin{array}{c}\text { sum } \\
{[\mathrm{mg} / \mathrm{g}]}\end{array}$ & c1:c2 & $\begin{array}{c}\mathrm{Cl}^{-} \\
{[\mathrm{mg} / \mathrm{g}]}\end{array}$ & $\begin{array}{l}\mathrm{SO}_{4}{ }^{2-} \\
{[\mathrm{mg} / \mathrm{g}]}\end{array}$ & $\begin{array}{c}\text { Sum } \\
{[\mathrm{mg} / \mathrm{g}]}\end{array}$ & c1:c5 & c2:c6 \\
\hline ES3 & 0.78 & 1.28 & 2.06 & 0.61 & 1.19 & 0.51 & 1.70 & 0.66 & 2.49 \\
\hline DS2 & 0.95 & 2.23 & 3.18 & 0.43 & 2.31 & 1.00 & 3.30 & 0.41 & 2.23 \\
\hline ES2 & 0.53 & 1.27 & 1.80 & 0.42 & 1.27 & 0.55 & 1.82 & 0.42 & 2.31 \\
\hline DS1 & 0.92 & 1.86 & 2.78 & 0.50 & 2.39 & 1.04 & 3.43 & 0.39 & 1.79 \\
\hline ES1 & 0.89 & 1.33 & 2.22 & 0.67 & 1.34 & 0.58 & 1.92 & 0.66 & 2.29 \\
\hline
\end{tabular}

Note: Column 1-4: measured in supernatant of conductivity measurement (eluted). Column 5-6: calculated from water content after dismantling based on ion content of Pearson water batch 1. c: column.

\subsection{Charge Balance of Cations and Anions in the Outflow}

The nearly constant concentrations of ions in the outflow added up to $204 \mathrm{mmol}(+) / \mathrm{L}$ cations and $217 \mathrm{mmol}(-) / \mathrm{L}$ anions in cell 9 and $210 \mathrm{mmol}(+) / \mathrm{L}$ cations and $217 \mathrm{mmol}(-) / \mathrm{L}$ anions in cell 10. In contrast, the cumulative amount in the total outflow volume was $924 \mathrm{mmol}(+)$ cations and $894 \mathrm{mmol}(-)$ anions in cell 9 and $631 \mathrm{mmol}(+)$ cations and $582 \mathrm{mmol}(-)$ anions in cell 10.

\subsection{Phase Content}

No changes in the mineral phase content were observed by XRD, but changed hydration state of the air-dry bentonite in DS blend material was observed by decrease of the basal space from $14.9 \AA$ to $<14 \AA$ prominently detectable from the $\mathrm{d} 001$ reflection (Figure S1, Supplementary Materials). Samples from ES showed no alteration to the original mineral phases of the N45 sand. Reflections corresponding to halite and gypsum appeared in ES samples from both cells, however, the amount was below the limit of quantification (Figure S2, Supplementary Materials).

STA curves of evolved water (Figure S3, Supplementary Materials) of air-dry bentonite in DS blend material showed a single dehydration peak compared to the characteristic dehydration peak with a shoulder at higher temperatures of the air-dry raw Secursol UHP with mainly exchangeable divalent $\mathrm{Ca}^{2+}$ and $\mathrm{Mg}^{2+}$. Only small changes were observed for the $\mathrm{CO}_{2}$ / carbonate traces in the bentonite after dismantling, where the shoulder between 200 and $300{ }^{\circ} \mathrm{C}$ and a small peak between 850 and $950{ }^{\circ} \mathrm{C}$ disappeared for the bentonite granules (Figure S3, Supplementary Materials) but were still visible in the blended DS material (data not shown). MS curves of evolved $\mathrm{SO}_{2}$ of the bentonite granules showed decomposition of sulfates between 400 and $700{ }^{\circ} \mathrm{C}, 800$ and $1000{ }^{\circ} \mathrm{C}$ and above $1000{ }^{\circ} \mathrm{C}$, 
that precipitated during drying of the samples (Figure S3, Supplementary Materials) even more pronounced in the blended DS material (data not shown).

ES material showed evolved water between $100-200{ }^{\circ} \mathrm{C}$ which corresponded to dehydration of sorbed water, not present in the original N45 material. Limited changes occur to the carbonate peak centered on $370{ }^{\circ} \mathrm{C}$ in N45 material, which was broadened for all ES and shifted to around $350^{\circ} \mathrm{C}$ in ES3 in both cells. A sharp carbonate peak also appeared at $607^{\circ} \mathrm{C}$ in ES3 of cell 10. Several ES also showed sulfate decomposition occurring between close to 900 and $1000^{\circ} \mathrm{C}$ and above $1000^{\circ} \mathrm{C}$ (Figure S4, Supplementary Materials).

\section{Discussion}

\subsection{Hydromechanical Behavior}

Fast breakthrough in both cells occurred very quickly due to the low dry density in DS during installation and the fabric resulting from blending of bentonite granules with fine sand. Thereby breakthrough occurred at saturation slightly below $100 \%$. Due to the low dry density and the reduced smectite content, the initial hydration state of the smectite had no influence on the breakthrough time and only a small influence on the axial stress (i.e., the swelling pressure). In cell 9, the smectite underwent a volume change by increasing of the unit cell in c direction of $26.5 \%$ due to the transition from $1 \mathrm{~W}$ into $2 \mathrm{~W}$ hydration. In cell 10 , the bentonite in the DS was already in $2 \mathrm{~W}$ hydration state and thus swelling lead only to small changes in the interlayer height (i.e., volume of unit cell). The swelling pressure in cell 9 was diminished by the larger inter-aggregate pores in the bentonite/sand blend in the DS where the swelling granules could expand.

The $1 \mathrm{~W}$ hydration state of the DS in cell 9 resulted in larger inflow permittivity at the beginning of the experiments and about $45 \%$ higher volume of Pearson water that went through the MiniSandwich compared to cell 10 until both cells were terminated.

Permeability in cell 9 showed three separate increases of about a half order of magnitude in the course of the experiment while the underlying trend was a continuous slow decrease after saturation and breakthrough. First, the breakthrough might have enabled discrete flow paths that caused a temporary faster fluid flow. These paths slowly closed and the permeability decreased again. The second and third increase of the permeability might have been similarly caused by local changes in the discrete fluid pathways due to the more pronounced swelling of the bentonite granules in cell 9 and a rearrangement of the inter-aggregate pores in the DS as described for pure bentonites in Meleshyn, et al. [23].

Accurate determination of swelling pressures under consideration of the heterogeneity of the MiniSandwich setup with different material segments is a challenge, because the axial effect of swelling DS is partly compensated by compacting the sand in ES. However, the selected experimental MiniSandwich setup corresponds to the arrangement used in real shaft conditions, which facilitates a realistic upscaling. As already mentioned, the measured axial stress necessary to ensure volume constancy during the test corresponds to the swelling pressure of the whole sandwich. Thereby, it is worth to noting that the applied maximum hydraulic pressure to ensure saturation over the experimental time is about half of the maximum swelling pressure of the MiniSandwich (swelling pressure for cell 9: 0.7 MPa; for cell 10: 0.6 MPa). Only in the beginning of the experiment was a stepwise increase of the axial strain required to ensure the water access to the material (Figures 2a and 3a). In the later state of the experiments, the axial load remained nearly constant, which indicated that stationary conditions for swelling and fluid flow were reached.

The initial gas permeability was also influenced by the hydration state of the bentonite and was slightly higher in cell 9 than in cell 10, while the resulting fluid permeability was similar in both cells after saturation at a very low value of $2.0 \times 10^{-17} \mathrm{~m}^{2}$ (Table 4). The initial gas permeability was in the range of the gas permeability of pure Secursol UHP, around $\times 10^{-12} \mathrm{~m}^{2}$, installed with $\rho_{\mathrm{d}}=1.31 \mathrm{~g} / \mathrm{cm}^{3}$ [5]. Deviation is again explained by the blending of the bentonite in the DS with fine sand. 


\subsection{Mineralogical/Geochemical Behavior}

No transformation of the smectite into another clay mineral in the DS of both cells in the course of the experiment could be detected by XRD, but XRD and STA measurements showed a different hydration behavior of the smectite equilibrated at ambient conditions ( $40-60 \%$ r.h. and $22-25^{\circ} \mathrm{C}$ ) after dismantling that was induced by the $\mathrm{Na}^{+}$exchange into the smectite interlayer observed by the CEC/EC measurements.

Furthermore, no changes occurred in the carbonate traces of the bentonite in DS of both cells after dismantling but MS curves of evolved $\mathrm{SO}_{2}$ showed decomposition of sulfates, while the raw Secursol UHP did not contain any sulfate. No crystalline sulfates were detectable by XRD. Thus, their concentration was very low in the bentonite samples and, in addition, they were precipitates that are expected to have a very fine crystal/grain size. Both low concentrations and small size lower the decomposition temperature during STA strongly up to $200 \mathrm{~K}$ compared to tabulated values [24] which makes assignment of the observed peaks in the MS curves of the evolved $\mathrm{SO}_{2}$ tenuous. In any case, decomposition temperature would increase in the order $\mathrm{Na}_{2} \mathrm{SO}_{4}<\mathrm{MgSO}_{4}<\mathrm{CaSO}_{4}$ and thus, the three intervals observed for evolved $\mathrm{SO}_{2}$ indicate all three sulfates precipitated either in the course of the experiment and/or mainly during drying of the samples after dismantling. Both processes cannot be distinguished without geochemical modelling or microfluidic experiments, like those described by Poonoosamy, et al. [25,26]. It seemed that pores in bentonite granules and inter-granular pores in DS blended materials formed different microreactors for dissolution/precipitation reactions.

The deficit between the sum of exchangeable cations and the CEC of the raw Secursol UHP could be explained by protons as the $\mathrm{pH}$ of the dispersed bentonite was slightly acidic. Protons are not detectable by ICP-OES in the supernatant of the CEC measurement. In the course of the experiment, these protons are only partially replaced by cations of the through flowing Pearson water. The sum of exchangeable cations in DS of both cells after dismantling equaled the CEC but a strong increase of soluble cations (Table 8) added to the sum of exchangeable cations. The charge imbalance of soluble cations and anions is explained by $\mathrm{HCO}_{3}{ }^{-}$.

Excess soluble sulfate in the DS and ES after dismantling indicate precipitation of sulfates in the course of the experiment and not only during drying of the samples after dismantling, although an enrichment in soluble cations was only observed in the DS of both cells. Thereby, Fe was observed only as soluble cation in DS but not in ES.

Imbalance of cation and anion concentrations in the solids and in the fluids indicate that neither ES nor DS materials were already in equilibrium with the Pearson water and observed ion concentration gradients in ES and DS of both cells have to be modelled for the throughflow experiment that was followed by a batch experiment with adapted numerical models for a mechanism-based description of the observed physical and geochemical processes.

\section{Summary and Conclusions}

The Sandwich sealing system, which consists of sealing segments (DS) of bentonite and equipotential segments (ES) of higher hydraulic conductivity, is a component in the German concept of shaft seals for nuclear waste deposits. Functionality was proved on semi-technical scale experiments. An in-situ large-scale demonstration experiment is running at the Mont Terri rock laboratory (Switzerland) that addresses the interaction between the Sandwich sealing system and the Opalinus clay. Prediction and evaluation of the in-situ behavior of the Sandwich sealing system require numerical models for a mechanism-based description of the observed physical and geochemical processes. These models can be validated with MiniSandwich experiments as performed in the current study.

Current MiniSandwich experiments were performed with blended Ca-bentonite (Secursol UHP) and Pearson water. Two experiments were run in parallel with DS installed at the same dry density but either in $1 \mathrm{~W}$ hydration state or in air-dry $(2 \mathrm{~W})$ state. Breakthrough and and almost complete saturation occurred at $0.3 \mathrm{MPa}$ injection pressure very fast after 20 days due to the modified fabric of the compacted bentonite blend and a reduced EMDD 
in the DS. While the influence of the hydration state of the smectite on the break-through was masked by blending the bentonite with a coarser material $4289 \mathrm{~mL}$ and $2984 \mathrm{~mL}$, respectively, passed the cell with DS installed in $1 \mathrm{~W}$ and $2 \mathrm{~W}$ state within $543 \mathrm{~d}$. Influence of the hydration state of DS during installation on initial and final hydraulic permeability $\left(2.0-2.7 \times 10^{17} \mathrm{~m}^{2}\right)$ was also masked by the blending of the DS material and hydraulic permeability in both cells was nearly constant, but still decreased slightly.

Swelling of DS resulted in slight compaction of ES, up to $7 \%$. There were no changes in the mineralogy of the DS and ES material, despite precipitated halite and sulfates occurring, and no changes in CEC of the bentonite blend were observed. While halite precipitated during drying after dismantling sulfates also could have precipitated in the course of the experiments. Exchangeable $\mathrm{Na}^{+}$strongly increased while exchangeable $\mathrm{Ca}^{2+}$ decreased. Exchangeable $\mathrm{Mg}^{2+}$ and $\mathrm{K}^{+}$remained nearly constant. Sodium concentration in the outflow indicated two different exchange processes, while the concentration of calcium and magnesium decreased potentially. Concentration of sulfate increased in the outflow until it reached a constant value, and concentration of chloride decreased to a minimum before it slightly increased to a constant value. While cations and anions in the outflow are nearly balanced with respect to their charge, the imbalance of cation and anion concentrations in the solids and in the cumulated outflow volume indicated that neither ES nor DS materials were already in equilibrium with the Pearson water.

Supplementary Materials: The following are available online at https: / www.mdpi.com/article/ 10.3390/min11101061/s1, X-ray fluorescence (XRF), Table S1: Chemical composition of Secursol UHP, Simultaneous Thermal Analysis (STA), Figure S1: XRD pattern of powdered DS samples, Figure S2: XRD patterns of powdered ES samples, Figure S3: Mass spectrometer curves for DS; Figure S4: mass spectrometer curves for ES.

Author Contributions: Conceptualization, K.E., F.K., R.S., C.R. and T.P.; methodology, K.E., E.B. and C.R.; analysis, C.R., E.B. and K.E.; resources, S.H. and R.D.; data curation, K.E.; writing-original draft preparation, K.E. and E.B.; writing-review and editing, K.E., E.B., C.R., T.P., R.S., F.K., S.H. and R.D.; visualization, K.E., C.R. and E.B.; project administration, K.E. and R.S.; funding acquisition, K.E. and R.S. All authors have read and agreed to the published version of the manuscript.

Funding: This research was funded by the German Federal Ministry for Economic Affairs and Energy (BMWi) under 02 E 11587 and 02 E 11799.

Data Availability Statement: Not Applicable.

Acknowledgments: The authors would like to thank Laure Delavernhe, Peter Bohac (former members of CMM) and Nadja Werling (IMB-CMM, KIT) for preparation of Pearson water, preliminary bentonite characterization, analysis of ions in outflow liquid and STA measurements. We thank Maya Denker and Elisabeth Eiche (AGW, KIT) for several IC measurements while our equipment was broken, Marita Heinle (IFG, KIT) for ICP-OES measurements and Silke Berberich (IMB-CMM, KIT) for many IC and ICP-OES measurements. Thanks also to Thomas Wilsnack and his colleagues (IBeWa) for measurement of the specific density of the bentonite and Matthias Schellhorn (SSKG) who made us aware of the bentonite Secursol UHP. Wiebke Baille and Michael Skubisch (RUB) are thanked for the determination of maximum dry density of N45 according to DIN 18126. We acknowledge support by the KIT-Publication Fund of the Karlsruhe Institute of Technology.

Conflicts of Interest: The authors declare no conflict of interest. The funders had no role in the design of the study; in the collection, analyses, or interpretation of data; in the writing of the manuscript, or in the decision to publish the results.

\section{References}

1. Gruner, M. Utilization of bentonite in wase disposal mining; Einsatz von Bentonit im Entsorgungsbergbau. Bergbau 2010, 61, 394-403.

2. Kudla, W.; Herold, P. Zusammenfassender Abschlussbericht für das Verbundvorhaben Schachtverschlüsse für Endlager für HochradioAktive Abfälle (ELSA-Phase 2): Konzeptentwicklung für Schachtverschlïsse und Test von Funktionselementen von Schachtverschlüssen; Technische Universität Bergakademie Freiberg; BGE Technology GmbH: Freiberg, Germany, 2021. 
3. Königer, F.; Emmerich, K.; Kemper, G.; Gruner, M.; Gaßner, W.; Nüesch, R.; Schuhmann, R. Moisture spreading in a multi-layer hydraulic sealing system (HTV-1). Eng. Geol. 2008, 98, 41-49. [CrossRef]

4. Schuhmann, R.; Emmerich, K.; Kemper, G.; Königer, F. Verschlusssystem mit Äquipotenzialsegmenten für die Untertägige Entsorgung (UTD und ELA) Gefährlicher Abfälle zur Sicherherstellung der Homogenen Befeuchtung der Dichtelemente und zur Verbesserung der Langzeitstabilität: Schlussbericht; Karlsruher Institut für Technologie: Karlsruhe, Germany, 2009.

5. $\quad$ Emmerich, K.; Schuhmann, R.; Königer, F.; Bohac, P.; Delavernhe, L.; Wieczorek, K.; Czaikowski, O.; Hesser, J.; Shao, H. Joint Project: Vertical Hydraulic Sealing System Based on the Sandwich Principle_Preproject (Sandwich-VP): Joint Final Report; Karlsruher Institut für Technologie: Karlsruhe, Germany, 2020.

6. Jobmann, M.; Bebiolka, A.; Jahn, S.; Lommerzheim, A.; Maßmann, J.; Meleshyn, A.; Mrugalla, S.; Reinhold, K.; Rübel, A.; Stark, L.; et al. Sicherheits- und Nachweismethodik für ein Endlager im Tongestein in Deutschland—Synthesebericht; BGE Technology GmbH: Peine, Germany, 2017; p. 137.

7. Roelke, C.; Emmerich, K.; Shao, H.; Popp, T.; Koeniger, F.; Schuhmann, R. The MiniSANDWICH: Fully Controlled Lab Testing and HM Modelling of a Bentonite Based SANDWICH Shaft Seal System; CMM: Karlsruhe, Germany, 2019; pp. $153-165$.

8. Pearson, F.J. Artificial Waters for Use in Laboratory and Field Experiments with Opalinus Clay: Status June 1998; Mont Terri Technical Note 99-31; Paul Scherrer Institut: Villigen, Switzerland, 1998.

9. Pearson, F.J.; Arcos, D.; Bath, A.; Boisson, J.Y.; Fernández, A.M.; Gäbler, H.E.; Gaucher, E.; Gautschi, A.; Griffault, L.; Hernán, P.; et al. Mont Terri Project: Geochemistry of Water in the Opalinus Clay Formation at the Mont Terri Rock Laboratory; Office Fédéral des Eaux et de la Géologie OFEG: Bern, Switzerland, 2003; Volume 5.

10. Van Loon, L.; Soler, J.; Bradbury, M. Diffusion of HTO, ${ }^{36} \mathrm{Cl}^{-}$and ${ }^{125} \mathrm{I}^{-}$in Opalinus Clay samples from Mont Terri: Effect of confining pressure. J. Contam. Hydrol. 2003, 61, 73-83. [CrossRef]

11. Emmerich, K.; Kemper, G.; Königer, F.; Schlaeger, S.; Gruner, M.; Gaßner, W.; Hofmann, M.; Nüesch, R.; Schuhmann, R. Saturation Kinetics of a Vertical Multilayer Hydraulic Sealing System Exposed to Rock Salt Brine. Vadose Zone J. 2009, 8, 332-342. [CrossRef]

12. Karnland, O.; Olsson, S.; Dueck, A.; Birgersson, M.; Nilsson, U.; Hernan-Håkansson, T.; Pedersen, K.; Nilsson, S.; Eriksen, T.E.; Rosborg, B. Long Term Test of Buffer Material at the Äspö Hard Rock Laboratory, LOT Project: Final Report on the A2 Test Parcel; TR-09-29; Svensk Kärnbränslehantering AB: Oskarshamn, Sweden, 2009.

13. Dohrmann, R.; Kaufhold, S. Characterization of the Second Package of the Alternative Buffer Material (ABM) Experiment; II Exchangeable Cation Population Rearrangement. Clays Clay Miner. 2017, 65, 104-121. [CrossRef]

14. Dohrmann, R.; Olsson, S.; Kaufhold, S.; Sellin, P. Mineralogical investigations of the first package of the alternative buffer material test-II. Exchangeable cation population rearrangement. Clay Miner. 2013, 48, 215-233. [CrossRef]

15. Wallis, I.; Idiart, A.; Dohrmann, R.; Post, V. Reactive transport modelling of groundwater-bentonite interaction: Effects on exchangeable cations in an alternative buffer material in-situ test. Appl. Geochem. 2016, 73, 59-69. [CrossRef]

16. Wersin, P.; Mazurek, M.; Waber, N.; Mäder, U.; Gimmi, T.; Rufer, D.; De Haller, A. Rock and Porewater Characterisation on Drillcores from the Schlattingen Borehole; NAGRA: Wettingen, Switzerland, 2013; p. 343.

17. Pearson, F.J. Artificial Waters for Use in Laboratory and Field Experiments with Opalinus Clay; Internal Report; Paul Scherrer Institut: Villigen, Switzerland, 1998; pp. 44-98.

18. Popp, T.; Rölke, C.; Salzer, K. Hydromechanical properties of bentonite-sand block assemblies with interfaces in engineered barrier systems. In Gas Generation and Migration in Radioactive Waste Repositories; Shaw, R., Ed.; Geological Society: London, UK, 2015; Volume 415, pp. 19-33.

19. DIN52102. Test Methods for Aggregates-Determination of Dry Bulk Density by the Cylinder Method and Calculation of the Ratio of Density; German Institute for Standardization: Berlin, Germany, 2013.

20. Emmerich, K.; Giraudo, N.; Schuhmann, R.; Schnetzer, F.; Kaden, H.; Thissen, P. On the Prediction of Water Contents in Na-Saturated Dioctahedral Smectites. J. Phys. Chem. C 2018, 122, 7484-7493. [CrossRef]

21. Doebelin, N.; Kleeberg, R. Profex: A graphical user interface for the Rietveld refinement program BGMN. J. Appl. Crystallogr. 2015, 48, 1573-1580. [CrossRef] [PubMed]

22. Meier, L.P.; Kahr, G. Determination of the cation exchange capacity (CEC) of clay minerals using the complexes of copper (II) ion with triethylenetetramine and tetraethylenepentamine. Clays Clay Miner. 1999, 47, 386-388. [CrossRef]

23. Meleshyn, A.Y.; Zakusin, S.V.; Krupskaya, V.V. Swelling Pressure and Permeability of Compacted Bentonite from 10th Khutor Deposit (Russia). Minerals 2021, 11, 742. [CrossRef]

24. Smykatz-Kloss, W. Differential Thermal Analysis, Application and Results in Mineralogy; Springer: Berlin, Germany, $1974 ;$ p. 188.

25. Poonoosamy, J.; Klinkenberg, M.; Deissmann, G.; Brandt, F.; Bosbach, D.; Mäder, U.; Kosakowski, G. Effects of solution supersaturation on barite precipitation in porous media and consequences on permeability: Experiments and modelling. Geochim. Cosmochim. Acta 2020, 270, 43-60. [CrossRef]

26. Poonoosamy, J.; Westerwalbesloh, C.; Deissmann, G.; Mahrous, M.; Curti, E.; Churakov, S.V.; Klinkenberg, M.; Kohlheyer, D.; von Lieres, E.; Bosbach, D. A microfluidic experiment and pore scale modelling diagnostics for assessing mineral precipitation and dissolution in confined spaces. Chem. Geol. 2019, 528, 119264. [CrossRef] 